Yara Backes

Koenraad F. van der Sluijs

David P. Mackie

Frank Tacke

Alexander Koch

Jyrki J. Tenhunen

Marcus J. Schultz

\section{Usefulness of suPAR as a biological marker in patients with systemic inflammation or infection: a systematic review}

Received: 18 December 2011

Accepted: 20 May 2012

Published online: 16 June 2012

(C) The Author(s) 2012. This article is published with open access at Springerlink.com
Y. Backes ( $)$ M. J. Schultz Department of Intensive Care Medicine, Academic Medical Center, University of Amsterdam, Meibergdreef 9, 1105 AZ Amsterdam, The Netherlands e-mail: yarabackes@ hotmail.com

Tel.: +31-20-5669111

Fax: +31-20-5669568

Y. Backes · K. F. van der Sluijs ·

M. J. Schultz

Laboratory of Experimental Intensive Care and Anesthesiology, Academic Medical Center, Meibergdreef 9,

1105 AZ Amsterdam, The Netherlands

D. P. Mackie

Department of Anesthesiology,

Red Cross Hospital, Vondellaan 13,

1942 LE Beverwijk, The Netherlands

F. Tacke $\cdot$ A. Koch

Department of Medicine III,

RWTH-University Hospital,

Pauwelsstrasse 30, 52074 Aachen, Germany

\section{J. J. Tenhunen}

Critical Care Medicine Research Group in Department of Intensive Care Medicine, Tampere University Hospital, PO BOX 2000, 33521 Tampere, Finland

\section{J. J. Tenhunen}

Department of Surgical Sciences/ Anaesthesiology and Intensive Care Medicine, Uppsala University, PO BOX 256, 75105 Uppsala, Sweden

Abstract Purpose: Systemic levels of soluble urokinase-type plasminogen activator receptor (suPAR) positively correlate with the activation level of the immune system. We reviewed the usefulness of systemic levels of suPAR in the care of critically ill patients with sepsis, SIRS, and bacteremia, focusing on its diagnostic and prognostic value.

Methods: A PubMed search on suPAR was conducted, including manual cross-referencing. The list of papers was narrowed to original studies of critically ill patients. Ten papers on original studies of critically ill patients were identified that report on suPAR in sepsis, SIRS, or bacteremia. Results: Systematic levels of suPAR have little diagnostic value in critically ill patients with sepsis, SIRS, or bacteremia. Systemic levels of suPAR, however, have superior prognostic power over other commonly used biological markers in these patients. Mortality prediction by other biological markers or severityof-disease classification system scores improves when combining them with suPAR. Systemic levels of suPAR correlate positively with markers of organ dysfunction and severity-of-disease classification system scores. Finally, systemic levels of suPAR remain elevated for prolonged periods after admission and only tend to decline after several weeks. Notably, the type of assay used to measure suPAR as well as the age of the patients and underlying disease affect systemic levels of suPAR. Conclusions: The diagnostic value of suPAR is low in patients with sepsis. Systemic levels of suPAR have prognostic value, and may add to prognostication of patients with sepsis or SIRS complementing severityof-disease classification systems and other biological markers.

Keywords Soluble uPAR . Soluble urokinase plasminogen activator receptor (suPAR) .

Biomarker - Intensive care . Critical illness $\cdot$ Sepsis 


\section{Introduction}

Systemic levels of soluble urokinase plasminogen activator receptor (suPAR), a protein derived from cleavage and release from the cell membrane-bound urokinase plasminogen activator receptor (UPAR), positively correlate with the activation level of the immune system. Numerous observational studies have shown systemic levels of suPAR to be increased with cancer [1,2], and various infectious and inflammatory diseases, including infections with human immunodeficiency virus (HIV) [3], malaria $[4,5]$, tuberculosis $[6,7]$, central nervous system infections [8], arthritis [9, 10], liver fibrosis [11], and inflammatory bowel disease [12]. In addition, systemic levels of suPAR have been shown to have prognostic value in predicting the severity and outcome in patients with cancer [13, 14]. Systemic levels of suPAR were also found to have a strong prognostic value in HIV-infected individuals $[15,16]$.

Systemic levels of suPAR are also increased in critically ill patients [17]. However, the usefulness of suPAR as a biological marker in critical illness is uncertain. The aim of this systematic review is to provide an overview of studies investigating the diagnostic and prognostic properties of suPAR in critically ill patients with sepsis, systemic inflammatory response syndrome, or bacteremia. We hypothesized that suPAR has both diagnostic and prognostic value in these inflammatory conditions. We also hypothesized that systemic concentrations of suPAR correlate with severity-of-disease classification system scores and other biological markers of severity of disease. Finally, we were interested in changes in systemic levels of suPAR after initiation of treatment to see whether suPAR has any potential for use in guiding therapy.

\section{Materials and methods}

Data sources

Two methods were used to identify relevant papers on suPAR as a biological marker in critically ill patients in the medical literature. First, an electronic search in the PubMed database was performed. Searches were also performed using the Cochrane Library and the Cochrane Database of Systematic reviews. Second, reference lists of identified and selected papers were reviewed for studies not identified with our search. Searches were restricted to original studies in humans and manuscripts written in English.

\section{Keywords (text word)}

The following keywords were used, alone or in combination, to identity relevant papers: (1) condition ("critical care" or "intensive care"), (2) subject ("human"), (3) test ("suPAR" or "soluble urokinase plasminogen activator receptor" or "soluble uPAR" or "soluble uPA receptor" or "soluble urokinase PA receptor" or "cleaved urokinase plasminogen activator receptor" or "cleaved uPAR" or "cleaved UPA receptor" or "cleaved urokinase PA receptor" or "cleaved CD87" or "soluble CD87"), and (4) disease ("systemic inflammation," "SIRS," "bacteremia," "sepsis," or "septic shock").

\section{Study selection}

Titles and abstracts were reviewed, and papers that reported on studies of suPAR in critically ill patients with systemic inflammation or infection were selected. Thus, only papers on studies of critically ill patients were included (i.e., studies of patients who were admitted to an intensive care unit or to a hospital with systemic inflammation or infection). In case of uncertainty the complete paper was obtained and evaluated. Inclusion of papers was not restricted by methodological quality or any other critically appraisal criteria other than the criteria formulated for data extraction.

\section{Quality assessment}

The quality of the included studies was evaluated by applying the 25 -item criteria developed by the Standards for Reporting of Diagnostic Accuracy (STARD) committee $[18,19]$. The maximum quality score that could be given to a study was 25 points over five categories. For each category, results were derived from consensus among three reviewers (Y.B, K.S and A.K).

\section{Data extraction}

Manuscripts were criticized along the following four subjects: (1) is suPAR a useful diagnostic marker in detection of infection, (2) is suPAR a useful prognostic marker in patients with SIRS, bacteremia or sepsis, (3) do systemic concentrations of suPAR correlate with disease severity scores and markers of organ failure in these patients, and (4) how do systemic levels of suPAR respond to initiation of treatment?

\section{Results}

Search results

The search performed in May 2011 in the PubMed database revealed nine papers as original studies [17, 20-27]. 
One additional paper was found in the reference list of identified and selected papers [28]. The Cochrane Library and the Cochrane Database of Systematic reviews revealed no reviews or meta-analyses of suPAR in critically ill patients. Quality evaluation of the included studies using the STARD checklist is presented in Table 1 . For 181 of the in total 250 items, complete agreement was observed between reviewers.

Study populations in the retrieved studies comprised patients with sepsis and/or septic shock, SIRS and bacteremia. Importantly, definitions for diagnoses varied among the studies. Table 2 presents the criteria used for diagnosis of each study. Of note, two studies by Kofoed et al. [22, 23] used the same cohort and data set to investigate either the diagnostic [22] or the prognostic [23] value of suPAR.

Seven studies evaluated the diagnostic value of suPAR [17, 22, 24-28]; six studies investigated the prognostic value of suPAR [20, 21, 23, 25-27]. Three studies correlated systemic levels of suPAR to disease severity scores [25, 27, 28]; three studies investigated changes of systemic levels of suPAR after initiation of treatment $[25$, $27,28]$.

In addition, the authors of two publications $[25,26]$ kindly provided their raw data, which were used for redrawing figures.

\section{Diagnostic value of suPAR}

Systemic levels of suPAR were significantly higher in critically ill patients, compared to healthy controls [17, 24-26, 28]. A gradual increase in levels of suPAR was seen from critically ill patients who did not fulfill SIRS criteria to patients with SIRS and patients with sepsis (Fig. 1) [25]. However, the area under the receiveroperating characteristic curve (AUC) for suPAR to discriminate between non-septic and septic ICU patients is reported to be poor (Fig. 2) [25].
Systemic levels of suPAR were significantly higher in patients with blood culture-positive bacteremia compared to healthy controls [26]. Levels of suPAR in patients with gram-positive bacteremia did not appear to be different from those with gram-negative bacteremia [27]. Also, suPAR seemed to have no value in discriminating patients with bacterial infection from patients with viral or parasitic infections [22]. Finally, levels of suPAR have been shown to be similar in patients with pulmonary sepsis and in those with extra-pulmonary sepsis [25].

Compared to other frequently used biological markers that can be measured easily with commercially available kits, including $\mathrm{C}$-reactive protein (CRP), procalcitonin (PCT), and soluble triggering receptor expressed on myeloid cells-1 (sTREM-1), suPAR added little to the diagnostic process $[22,25]$.

\section{Prognostic value of suPAR}

Systemic levels of suPAR were significantly higher in critically ill patients with fatal outcomes compared to patients who survive critical illness [20, 21, 23, 25-27]. Although systemic levels of suPAR were consistently higher in non-survivors on admission as well as on day 3 and 7, the AUC for suPAR to predict ICU mortality in general ICU patients remained moderate (Fig. 3) [25]. Similar findings were seen in patients with sepsis (Fig. 4) [25]. In patients who fulfilled at least two criteria for SIRS, an AUC of 0.80 (cutoff value $6.61 \mu \mathrm{g} / \mathrm{l}$, sensitivity $89 \%$, specificity $63 \%$ ) for short-term mortality and an AUC of 0.69 (cutoff value $6.61 \mu \mathrm{g} / \mathrm{l}$, sensitivity $89 \%$, specificity $63 \%$ ) for long-term mortality was found [23]. Of note, $64 \%$ of these patients suffered from bacterial infection, and $15 \%$ had positive blood cultures. In addition, the AUC in patients with positive blood cultures was 0.75 (cutoff value $9.25 \mathrm{ng} / \mathrm{ml}$, sensitivity $79 \%$, specificity $68 \%$ ) for 1-month mortality and AUCs of 0.80 (cutoff value $8.3 \mathrm{ng} / \mathrm{ml}$, sensitivity $71 \%$, specificity

Table 1 Quality evaluation of the included studies using the Standard for Reporting of Diagnostic Accuracy (STARD) checklist [18, 19]

\begin{tabular}{|c|c|c|c|c|c|c|c|c|}
\hline \multicolumn{3}{|c|}{ Maximum score for each category ${ }^{\mathrm{a}}$} & $\begin{array}{l}\text { Title/abstract/keywords } \\
1\end{array}$ & $\begin{array}{l}\text { Introduction } \\
1\end{array}$ & $\begin{array}{l}\text { Methods } \\
11\end{array}$ & $\begin{array}{l}\text { Results } \\
11\end{array}$ & $\begin{array}{l}\text { Discussion } \\
1\end{array}$ & $\begin{array}{l}\text { Total } \\
25\end{array}$ \\
\hline Mizukami & [17] & 1995 & 1 & 0 & 6 & 3 & 0 & 10 \\
\hline Molkanen & {$[20]$} & 2011 & 1 & 1 & 8 & 8 & 1 & 19 \\
\hline Moller & {$[21]$} & 2006 & 1 & 1 & 7 & 6 & 1 & 16 \\
\hline Kofoed & [22] & 2007 & 1 & 1 & 10 & 8 & 1 & 21 \\
\hline Kofoed & [23] & 2008 & 1 & 1 & 8 & 7 & 1 & 18 \\
\hline Kofoed & [24] & 2006 & 0 & 1 & 7 & 3 & 1 & 12 \\
\hline Koch & [25] & 2011 & 1 & 1 & 8 & 6 & 1 & 17 \\
\hline Wittenhagen & [26] & 2004 & 1 & 1 & 7 & 5 & 1 & 15 \\
\hline Huttunen & [27] & 2011 & 1 & 1 & 8 & 8 & 1 & 19 \\
\hline Florquin & [28] & 2001 & 0 & 1 & 6 & 4 & 0 & 11 \\
\hline
\end{tabular}

${ }^{a}$ For each category, results are derived from consensus among three reviewers as the number of items from the checklist present in the original article 
Table 2 Patients characteristics of the included studies

\begin{tabular}{|c|c|c|c|c|}
\hline Study & References & Criteria used for diagnosis & $\begin{array}{l}\text { Diagnosis on admission } \\
\text { as described by the } \\
\text { authors (no. of patients) }\end{array}$ & Type of test used \\
\hline Mizukami & {$[17]$} & $\begin{array}{l}\text { A recognized source of infection or a } \\
\text { hemodynamic profile suggestive of } \\
\text { sepsis, along with fever, granulocytosis, } \\
\text { and/or respiratory failure requiring } \\
\text { ventilatory support }\end{array}$ & $\begin{array}{l}\text { Clinical sepsis } \\
\text { syndrome (13) }\end{array}$ & ELISA \\
\hline Molkanen & [20] & Blood culture positive for $S$. aureus & Bacteremia (59) & ELISA \\
\hline Moller & [21] & Blood culture positive for $S$. pneumoniae & Bacteremia $(128)^{\mathrm{a}}$ & ELISA \\
\hline Kofoed & [22] & At least two SIRS criteria ${ }^{\mathrm{b}}$ & SIRS (151) & Luminex multiplex assay \\
\hline Kofoed & [23] & At least two SIRS criteria ${ }^{b}$ & SIRS (151) & $\begin{array}{l}\text { Luminex multiplex assay } \\
\text { and ELISA }\end{array}$ \\
\hline Kofoed & {$[24]$} & $\begin{array}{l}\text { Blood culture positive for Pneumococcus } \\
\text { pneumonia or E. coli and at least two } \\
\text { SIRS criteria }\end{array}$ & Bacterial sepsis (10) & $\begin{array}{l}\text { Luminex multiplex assay } \\
\text { and ELISA }\end{array}$ \\
\hline Koch & {$[25]$} & Severe sepsis and septic shock criteria ${ }^{b}$ & $\begin{array}{l}\text { Severe sepsis and septic } \\
\text { shock (197) }\end{array}$ & ELISA \\
\hline Wittenhagen & [26] & Blood culture positive for $S$. pneumoniae & Bacteremia (141) & ELISA \\
\hline Huttunen & {$[27]$} & $\begin{array}{l}\text { Blood culture positive for } S \text {. aureus, } S \text {. } \\
\text { pneumonia, } \beta \text {-haemolytic streptococcus } \\
\text { or E. coli }\end{array}$ & Bacteremia (132) & ELISA \\
\hline Florquin & {$[28]$} & $\begin{array}{l}\text { Acute symptoms of urinary tract infection, } \\
\text { pyuria, urine gram staining with gram- } \\
\text { bacteria, and metabolic or hematologic } \\
\text { signs of systemic infection, including } \\
\text { two of the three indicators: tachycardia, } \\
\text { leukocytosis or fever }\end{array}$ & Urosepsis & ELISA \\
\hline
\end{tabular}

a A total of 133 patients were included in this study. Data for ${ }^{b}$ Criteria as recommended and defined in the American College of suPAR were accessible from 128 of the patients Chest Physicians/Society of Critical Care Medicine (ACCP/SCCM) Consensus Conference [29]

Fig. 1 Systemic levels of suPAR in healthy controls and critically ill patients with SIRS or sepsis, and patients with bacteremia. Systemic levels of suPAR are significantly higher in patients with sepsis, as compared to patient without sepsis or patients with SIRS. their interquartile range.

Extremes were excluded from the figure. Stars indicate the Reproduced with permission from [25] and [26] Data represent medians with level of statistical difference.

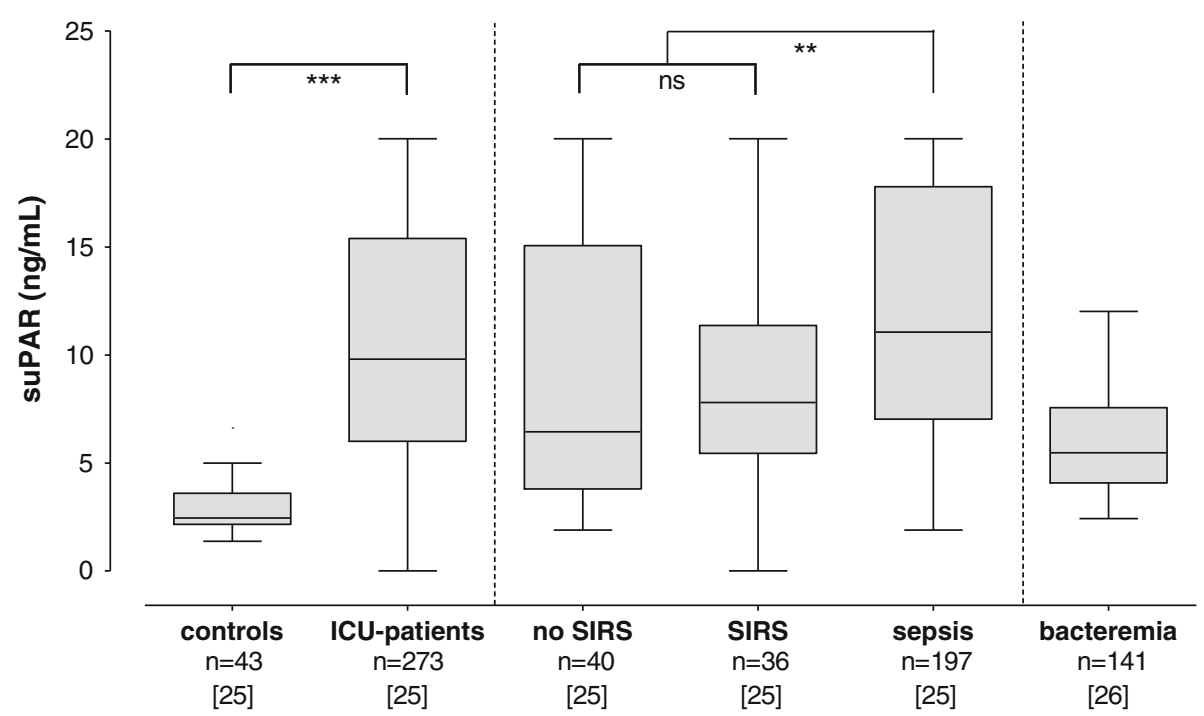

$78 \%$ ) and 0.84 (cutoff value $11 \mathrm{ng} / \mathrm{ml}$, sensitivity $83 \%$, specificity $76 \%$ ) for hospital mortality [20, 21, 27]. Notably, changes in systemic levels of suPAR over the first few days in the ICU did not appear to differ between survivors and non-survivors [25].
As a single biological marker, suPAR was superior in predicting mortality compared to other frequently used biological markers, including CRP, PCT and sTREM-1 [20, 21, 23, 25] (Table 3). In addition, the prognostic performance of suPAR improved when combined with 


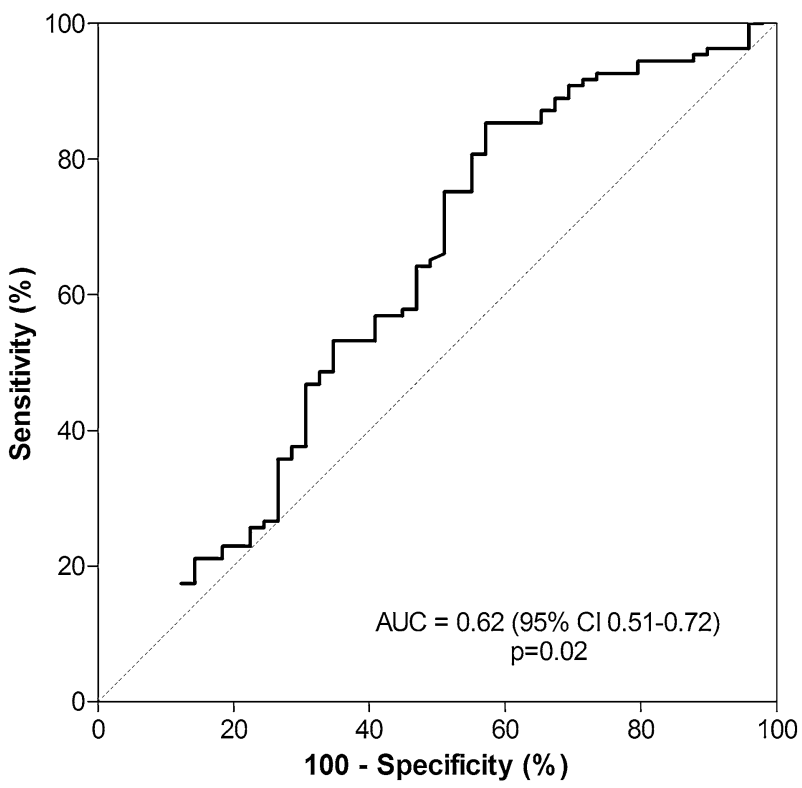

Fig. 2 Diagnostic power of suPAR. ROC curve analysis showing the diagnostic power of systemic levels of suPAR in predicting sepsis on admission. AUC, area under the curve. The $p$ value indicates the level of statistical significance. Adapted with permission from [25] other biological markers or age [23] (Table 3). While the ability of suPAR to predict mortality was poor compared to the conventional simplified acute physiology score (SAPS) II $[23,25]$, the prognostic performance of SAPS II improved when combined with suPAR levels [23] (Table 3).

Levels of suPAR did not seem predictive of length of ICU stay [25]. High systemic levels of suPAR were associated with the need for ICU admission, and need for vasopressors and mechanical ventilation [27].

Correlation between suPAR and organ failure markers and disease severity scores

In non-septic and septic patients, systemic levels of suPAR correlated with several markers of organ dysfunction, including creatinine, urea and cystatin C (kidney), bilirubin, gamma glutamyl transpeptidase, alkaline phosphatase and albumin (liver), and INR and antithrombin (coagulation) [25]. Similar associations were described for blood culture-positive bacteremic patients [27].

In the general ICU population, systemic levels of suPAR correlated with Acute Physiology and Chronic
Fig. 3 Prognostic power of suPAR in ICU patients. Box plot graphics and ROC curve analyses showing the prognostic power of suPAR for mortality on admission, and day 3 and 7 after admission in ICU patients. AUC, area under the curve. The $\mathrm{P}-$ value indicates the level of statistical significance. Adapted with permission from [25]
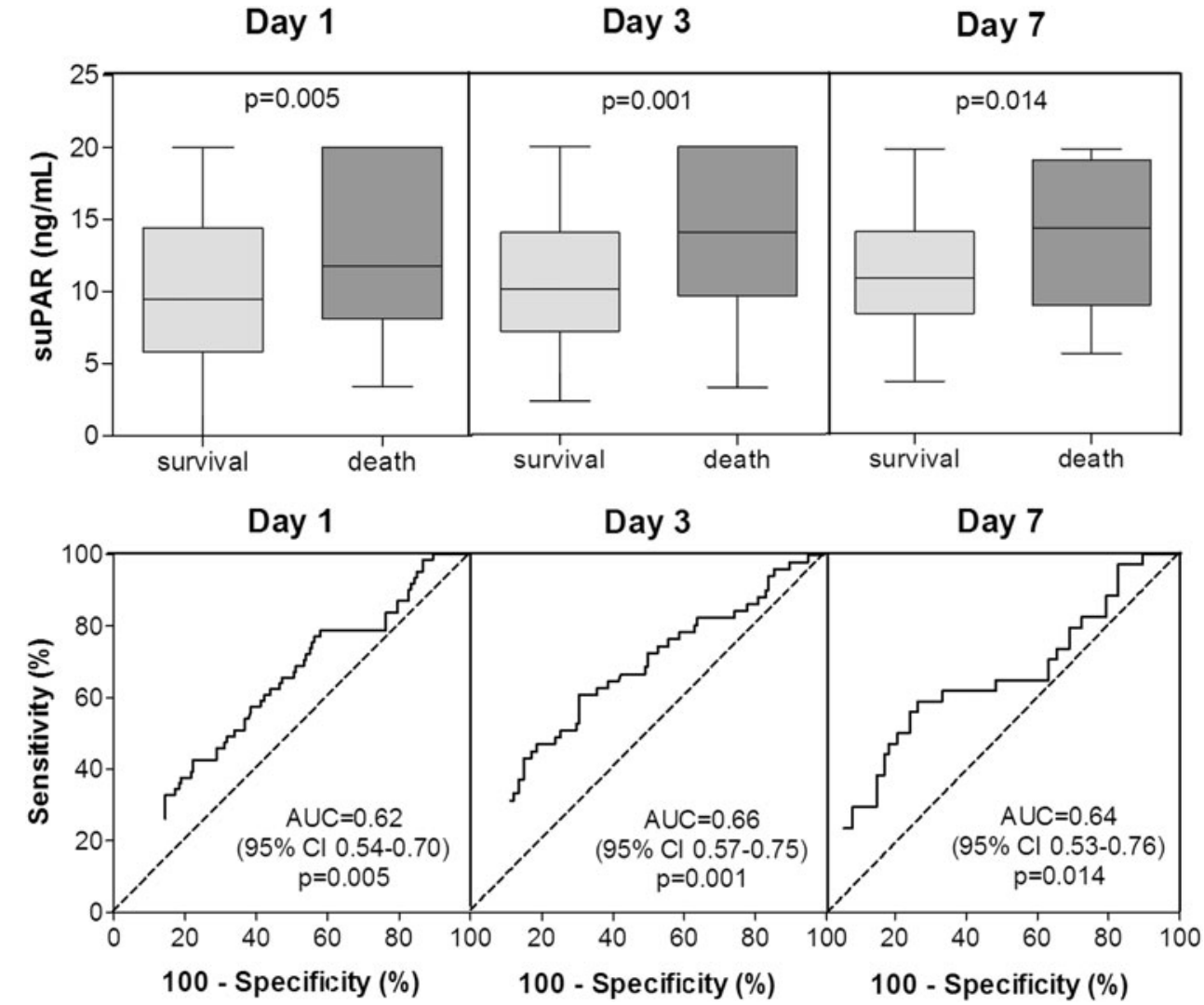
Fig. 4 Prognostic power of suPAR in patients with sepsis. Box plot graphics and ROC curve analyses showing the prognostic power of suPAR for mortality on admission in patients with sepsis. $A U C$ area under the curve. The $p$ value indicates the level of statistical significance. Adapted with permission from [25]

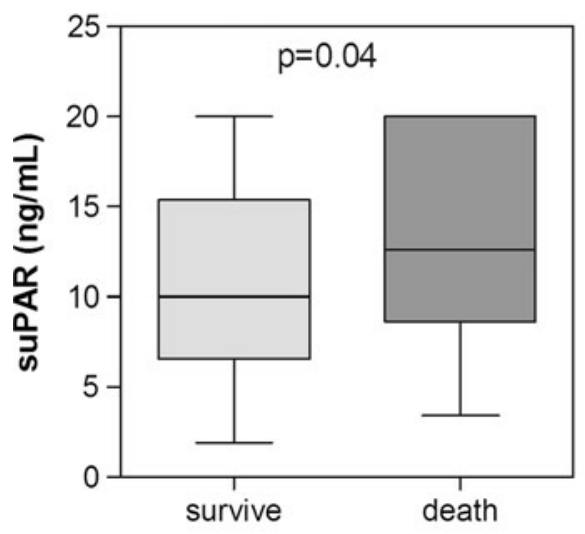

Health Evaluation (APACHE) II scores, SAPS II, and Sequential Organ Failure Assessment (SOFA) scores [25]. In patients with sepsis, systemic levels of suPAR also correlated with APACHE II scores and SAPS II, but not with SOFA scores [25]. Of note, in patients with urosepsis no correlation with APACHE II scores was found [28]. In bacteremic patients, however, high suPAR levels were associated with high SOFA scores [27].

Systemic levels of suPAR after initiation of antimicrobial treatment

Three studies evaluated levels of suPAR after the initiation of treatment [25, 27, 28]. Systemic levels of suPAR remained elevated for hours in patients with urosepsis [28] and for at least the first week in a general ICU population [25]. In bacteremic patients, systemic levels of suPAR tended to decline only after several weeks [27].

Factors that influence levels of suPAR and/or its performance

Some studies showed that the type of assay used to measure suPAR as well as age of patients and underlying diseases affected levels of suPAR and/or its performance.

The types of test used for measurement of suPAR are decribed in Table 2. In one study the suPARnostic ${ }^{\mathrm{TM}}$ (Virogates, Copenhagen, Denmark) assay was compared with the Luminex assay in the same cohort of patients and showed a better prognostic performance (AUC of $0.80 \mathrm{vs.}$ 0.68 in predicting short-term mortality; AUC of 0.69 vs. 0.54 in predicting long-term mortality) [23]. Another study found a correlation coefficient between suPAR concentrations obtained with a Luminex (8-plex) assay and a suPAR ELISA of 0.95 with a $95 \%$ limits of agreement between 99-140\% [24].

Studies that investigated systemic levels of suPAR in relation to age are contradictory [20, 21, 25-27]. Two studies found no correlation between systemic levels of suPAR and age [25, 26]. However, two other studies suggested higher levels of suPAR in elderly patients [20, 27], and one study showed lower levels in very old patients [21]. Of note, in patients with bacteremia with age $\geq 75$ years, differences in systemic levels of suPAR between surviving and non-surviving patients were not significant [21].

Underlying diseases may affect levels of suPAR. In patients with bacteremia levels of suPAR were higher in patients with chronic alcohol abuse or liver disease, while levels were lower in patients with cancer [26, 27]. Interestingly, after adjusting for possible confounders, including age and underlying diseases, systemic levels of suPAR remained independently prognostic for mortality [20, 25-27].

\section{Discussion}

This systematic review shows that although systemic levels of suPAR are elevated with SIRS, bacteremia, and sepsis, its diagnostic value is low, as suPAR is a nonspecific marker of inflammation. Systemic levels of suPAR, however, do have prognostic value, with higher levels being associated with increased mortality. Systemic levels of suPAR correlate positively with severity-ofdisease classification scores. Systemic levels of suPAR also correlate positively with several markers of organ dysfunction. After initiation of therapy, levels of suPAR decline only on long-term follow-up.

Ideally, biological markers of sepsis should differentiate among bacterial, viral and fungal infection, and between systemic sepsis and local infection. Over 150 biological markers have been clinically evaluated for use in sepsis [30]. Relatively few biological markers, however, have been used for diagnosing (the type of) sepsis, and none has sufficient sensitivity or specificity to be used routinely in daily practice [30]. C-reactive protein and 
Table 3 Prognostic value of suPAR to predict mortality as compared to other biological markers and disease severity scores

\begin{tabular}{|c|c|c|c|c|c|c|}
\hline Ability to predict & Parameter & $\begin{array}{l}\text { AUC } \\
(95 \% \text { CI })\end{array}$ & Cutoff & $\begin{array}{l}\text { Sensitivity } \\
(\%)\end{array}$ & $\begin{array}{l}\text { Specificity } \\
(\%)\end{array}$ & References \\
\hline \multicolumn{7}{|c|}{ General intensive care unit population } \\
\hline \multirow[t]{5}{*}{ ICU mortality } & suPAR & $0.67(0.54-0.80)$ & - & - & - & \multirow[t]{5}{*}[25]{} \\
\hline & CRP & $0.54(0.40-0.68)$ & - & - & - & \\
\hline & PCT & $0.58(0.46-0.71)$ & - & - & - & \\
\hline & SAPS II & $0.83(0.74-0.91)$ & - & - & - & \\
\hline & APACHE II & $0.60(0.45-0.74)$ & - & - & - & \\
\hline \multirow[t]{5}{*}{ Long-term mortality $^{a}$} & SUPAR & $0.67(0.55-0.78)$ & - & - & - & \multirow[t]{5}{*}[25]{} \\
\hline & CRP & $0.55(0.43-0.67)$ & - & - & - & \\
\hline & PCT & $0.62(0.50-0.74)$ & - & - & - & \\
\hline & SAPS II & $0.73(0.62-0.84)$ & - & - & - & \\
\hline & APACHE II & $0.63(0.51-0.75)$ & - & - & - & \\
\hline \multicolumn{7}{|c|}{ Patients with infectious diseases ${ }^{\mathrm{b}}$} \\
\hline \multirow[t]{9}{*}{ 30-Day mortality } & suPAR & $0.80(0.69-0.92)$ & $6.61 \mu \mathrm{g} / \mathrm{L}$ & 89 & 63 & \multirow[t]{9}{*}[23]{} \\
\hline & sTREM-1 & $0.69(0.52-0.86)$ & $9.00 \mu \mathrm{g} / \mathrm{L}$ & 100 & 36 & \\
\hline & MIF & $0.65(0.46-0.84)$ & $1.27 \mu \mathrm{g} / \mathrm{L}$ & 78 & 54 & \\
\hline & suPAR + age & $0.92(0.86-0.97)$ & 3.43 & 100 & 78 & \\
\hline & suPAR + sTREM-1 + MIF & $0.84(0.70-0.98)$ & 2.40 & 67 & 93 & \\
\hline & suPAR + sTREM-1 + MIF + age & $0.93(0.88-0.98)$ & 3.40 & 100 & 81 & \\
\hline & SAPS II & $0.89(0.80-0.98)$ & 22.5 & 100 & 68 & \\
\hline & SOFA & $0.80(0.65-0.94)$ & 4.5 & 44 & 95 & \\
\hline & SUPAR + SAPS II & $0.93(0.86-1.00)$ & - & - & - & \\
\hline \multirow[t]{9}{*}{ 180-Day mortality } & suPAR & $0.69(0.57-0.81)$ & $6.61 \mu \mathrm{g} / \mathrm{L}$ & 68 & 64 & \multirow[t]{9}{*}[23]{} \\
\hline & sTREM-1 & $0.69(0.58-0.80)$ & $9.00 \mu \mathrm{g} / \mathrm{L}$ & 95 & 38 & \\
\hline & MIF & $0.54(0.39-0.68)$ & $0.81 \mu \mathrm{g} / \mathrm{L}$ & 42 & 72 & \\
\hline & suPAR + age & $0.86(0.79-0.94)$ & 4.62 & 79 & 83 & \\
\hline & suPAR + sTREM-1 + MIF & $0.72(0.59-0.84)$ & 1.87 & 58 & 83 & \\
\hline & suPAR + sTREM-1 + MIF + age & $0.87(0.79-0.94)$ & 4.55 & 79 & 84 & \\
\hline & SAPS II & $0.91(0.86-0.96)$ & 22.5 & 100 & 73 & \\
\hline & SOFA & $0.75(0.64-0.86)$ & 1.5 & 74 & 61 & \\
\hline & suPAR + SAPS II & $0.92(0.87-0.97)$ & - & - & - & \\
\hline \multicolumn{7}{|l|}{ Bacteremic patients } \\
\hline \multirow[t]{2}{*}{ 1-Month mortality } & suPAR & $0.75(0.62-0.89)$ & $9.25 \mathrm{ng} / \mathrm{ml}$ & 79 & 68 & \multirow[t]{2}{*}[20]{} \\
\hline & CRP & $0.60(0.44-0.75)$ & - & - & - & \\
\hline \multirow[t]{2}{*}{ Hospital mortality } & suPAR & $0.80(0.62-0.90)$ & $8.3 \mathrm{ng} / \mathrm{mL}$ & 71 & 78 & \multirow[t]{2}{*}[21]{} \\
\hline & CRP & $0.76(0.59-0.86)$ & $1360 \mathrm{nmol} / \mathrm{L}$ & 82 & 69 & \\
\hline
\end{tabular}

APACHE II Acute Physiology and Chronic Health Evaluation II score, CRP C-reactive protein, MIF macrophage migration inhibitory factor, $P C T$ procalcitonin, SAPS II Simplified Acute Physiology Score II, SOFA Sequential Organ Failure Assessment, sTREM-1 soluble triggering receptor expressed on myeloid cells type 1

procalcitonin are the most widely used values, despite their limited ability to distinguish sepsis from other inflammatory conditions [30]. Our review showed suPAR to have low diagnostic value in patients with SIRS, bacteremia, or sepsis, even lower than CRP, PCT, and sTREM-1.

The majority of the biological markers investigated in septic patients have been assessed according to their prognostic value [30]. Traditional markers such as fever, white blood cell count, and CRP levels are not reliable for assessing disease severity and mortality risk [30, 31]. Procalcitonin seems to be an improvement on these markers, but is not ideal [32-34]. Although PCT has repeatedly been shown to have prognostic value in critically ill patients, the value of a single level on admission is limited [35]. The compiled data in this paper suggest a Long-term follow-up period: median 348 days (range 29-884)

b Of these patients, $64 \%$ suffered from bacterial infection, and $15 \%$ had positive blood cultures

that suPAR has superior prognostic value compared to commonly used biological markers, including PCT. Moreover, in contrast to most other markers, circadian changes in plasma levels of suPAR are minimal $[28,36]$. Measurement is therefore largely independent of the sampling schedule, improving the potential of suPAR as a marker in clinical routine.

It has been suggested that suPAR is involved in the plasminogen-activating pathway, inflammation, and the modulation of cell adhesion, migration, and proliferation [37]. Soluble urokinase-type plasminogen activator receptor derives from proteolytic cleavage and release from cell membrane-bound urokinase plasminogen activator receptor (uPAR). Both membrane-bound and soluble uPARs have been shown to bind to integrins $[38,39]$, and have been proposed to be involved in cell adhesion and 
proliferation. The soluble form of uPAR has been reported to have direct chemotactic properties, which may facilitate recruitment of inflammatory cells such as neutrophils and monocytes [40, 41], and the mobilization of hematopoietic stem cells [42]. In addition to its role in adhesion and migration, suPAR has recently been shown to inhibit neutrophil efferocytosis [43], while the membrane-bound form of uPAR has been shown to facilitate phagocytosis of bacteria [44]. Impaired engulfment of apoptotic neutrophils or bacteria has been associated with poor outcome in preclinical models of sepsis $[44,45]$. Cleavage of uPAR may therefore reflect a functional impairment of the host defense rather than a surrogate marker of inflammation, which might explain the higher prognostic value of suPAR compared to other biological markers.

Although suPAR alone did not perform as well as the SAPS II score, this does not necessarily preclude its use in prognostication. APACHE II score, SAPS II, SOFA score, and other scoring systems estimating the risk of mortality have become increasingly popular in the field of research with critically ill patients over the last decades. However, in clinical practice these scoring systems have important limitations. Data collection requires multiple laboratory measurements and the computation of multiple variables, and is labor intensive and expensive [46-48]. Therefore, the application of these scoring systems may be limited, particularly when health care is subject to financial constraint. Soluble urokinase-type plasminogen activator receptor may have other important advantages. Only one blood sample instead of multiple clinical and laboratory measurements are needed. Measurement of suPAR can be performed using a simple ELISA. In addition, suPAR is stable in plasma samples subjected to repeated freeze-thaw procedures [49], increasing its practicality as a practical biological marker. Thus, based on the findings that systemic levels of suPAR are a strong and robust marker of mortality risk, one could speculate that suPAR will eventually serves as a quick, technically simple and inexpensive alternative to the current sophisticated severity-of-disease classification systems. Future studies are needed to address this hypothesis.

The usefulness of suPAR in mortality prediction of individual patients is uncertain. One can hypothesize that specific therapeutic strategies should be restricted to patients with a certain level of suPAR as an alternative to APACHE II or SAPS II scores. Risk stratification and prediction of outcome can be used for safe decision making on the need for hospitalization or ICU admission and identifying patients at low risk suitable for outpatient management. Thus, suPAR may eventually help to triage patients. Also, predicted mortalities can be averaged for groups of patients in order to specify the group's morbidity. However, conclusions should be drawn with some caution. First, patient numbers in studies of suPAR are still very low. More and larger studies are needed to better define the prognostic power of suPAR in critically ill patients.
Notably, systemic levels of suPAR remain elevated long after clinical recovery and only decline after several weeks. Therefore, the use of suPAR as a biological marker for guiding therapy is probably limited. However studies addressing this issue are lacking.

Importantly, the type of assay used to measure suPAR, as well as age and presence or absence of underlying diseases all influence suPAR levels. The difference in prognostic performance between different assays can be explained by the fact that the Luminex assay uses a polyclonal detection antibody, whereas the suPARnostic $^{\text {TM }}$ assay uses monoclonal antibodies selected because of their superior clinical value in HIV disease progression [23]. On the other hand, the Luminex assay has its advantage in measuring multiple analytes at the same time [24]. With the prognostic value of suPAR increasing in combination with other markers, this might compensate for the slightly impaired performance.

The finding that age as well as underlying disease influences the systemic level of suPAR is of limited relevance as both age and underlying diseases are known to increase mortality risk in critically ill patients $[50,51]$. Systemic levels of suPAR remained independently prognostic for mortality after adjusting for age and/or underlying diseases [20, 25-27]. As with other markers such as CRP and PCT, experience will eventually dictate the value of suPAR levels in diverse clinical situations.

Of interest, suPAR is not only present in human plasma or serum, but can also be found in other body fluids, including urine, cerebrospinal fluid [37], and pleural, pericardial, and peritoneal fluids [17]. The number of studies investigating the value of suPAR in body fluids other than plasma or serum, however, is very limited. It would be interesting to evaluate the value of local levels of suPAR in other body fluids, i.e., in bronchoalveolar lavage fluid of patients with frequent pulmonary complications, such as acute lung injury or ventilatorassociated pneumonia.

Finally, this review has limitations. An important limitation is that not all studies used the ACCP/SCCM criteria for the diagnosis of bacteremia, SIRS, and sepsis. Differences in used definitions may hamper interpretation of the data. However, since the aim of this review is to describe the value of suPAR in patients with systemic infection or inflammation and not to compare patients with SIRS with patients with bacteremia or sepsis, overlap between these groups may not hamper interpretation of the results.

The most common limitation of any systematic review is publication bias. Unpublished materials were not found and thus not used. Another limitation is the small number of studies that could be included. Soluble urokinase-type plasminogen activator receptor is a relatively new marker, and the number of publications in critically ill patients is still low. Also, studies on the prognostic value of suPAR were very restricted as they focused only on mortality. No 
conclusions can be drawn on the prognostic value of suPAR on other clinical outcomes, such as length of ICU and hospital stay, and duration of mechanical ventilation.

\section{Conclusions}

Soluble urokinase-type plasminogen activator receptor seems a promising prognostic marker in critically ill patients. Currently, studies are limited to the predictive potential to estimate the mortality risk in observational designs. Future studies should demonstrate whether prognostic assessment translates into better clinical outcomes and a higher quality of patients care.

Acknowledgments We thank the authors of two publications [25, 26 ] for providing us with the original data of their investigation.

Conflicts of interest The authors declare that they have no conflict of interest.

Open Access This article is distributed under the terms of the Creative Commons Attribution License which permits any use, distribution, and reproduction in any medium, provided the original author(s) and the source are credited.

\section{References}

1. Stephens RW, Pedersen AN, Nielsen HJ, Hamers MJ, Høyer-Hansen G, Rønne E, Dybkjaer E, Danø K, Brünner N (1997) ELISA determination of soluble urokinase receptor in blood from healthy donors and cancer patients. Clin Chem 43:1868-1876

2. Sier CF, Stephens R, Bizik J, Mariani A, Bassan M, Pedersen N, Frigerio L, Ferrari A, Dan $\varnothing$ K, Brünner N, Blasi F (1998) The level of urokinase-type plasminogen activator receptor is increased in serum of ovarian cancer patients. Cancer Res 58:1843-1849

3. Ostrowski SR, Katzenstein TL, Piironen T, Gerstoft J, Pedersen BK, Ullum H (2004) Soluble urokinase receptor levels in plasma during 5 years of highly active antiretroviral therapy in HIV-1-infected patients. J Acquir Immune Defic Syndr 35:337-342

4. Perch M, Kofoed P, Fischer TK, Có F, Rombo L, Aaby P, Eugen-Olsen J (2004) Serum levels of soluble urokinase plasminogen activator receptor is associated with parasitemia in children with acute Plasmodium falciparum malaria infection. Parasite Immunol 26:207-211

5. Ostrowski SR, Ullum H, Goka BQ, Høyer-Hansen G, Obeng-Adjei G, Pedersen BK, Akanmori BD, Kurtzhals JA (2005) Plasma concentrations of soluble urokinase-type plasminogen activator receptor are increased in patients with malaria and are associated with a poor clinical or a fatal outcome. J Infect Dis 191:1331-1341

6. Eugen-Olsen J, Gustafson P, Sidenius N, Fischer TK, Parner J, Aaby P, Gomes VF, Lisse I (2002) The serum level of soluble urokinase receptor is elevated in tuberculosis patients and predicts mortality during treatment: a community study from Guinea-Bissau. Int J Tuberc Lung Dis 6:686-692
7. Ostrowski SR, Ravn P, Hoyer-Hansen G, Ullum H, Andersen AB (2006) Elevated levels of soluble urokinase receptor in serum from mycobacteria infected patients: still looking for a marker of treatment efficacy. Scand J Infect Dis 38:1028-1032

8. Garcia-Monco JC, Coleman JL, Benach JL (2002) Soluble urokinase receptor (uPAR, CD 87) is present in serum and cerebrospinal fluid in patients with neurologic diseases. J Neuroimmunol 129:216-223

9. Slot O, Brunner N, Locht H, Oxholm P, Stephens RW (1999) Soluble urokinase plasminogen activator receptor in plasma of patients with inflammatory rheumatic disorders: increased concentrations in rheumatoid arthritis. Ann Rheum Dis 58:488-492

10. Pliyev BK, Menshikov MY (2010) Release of the soluble urokinase-type plasminogen activator receptor (suPAR) by activated neutrophils in rheumatoid arthritis. Inflammation 33:1-9

11. Andersen ES, Ruhwald M, Moessner B, Christensen PB, Andersen O, EugenOlsen J, Weis N (2011) Twelve potential fibrosis markers to differentiate mild liver fibrosis from cirrhosis in patients infected with chronic hepatitis $\mathrm{C}$ genotype 1 . Eur J Clin Microbiol Infect Dis 30:761-766

12. Lonnkvist $\mathrm{MH}$, Theodorsson $\mathrm{E}$, Holst M, Ljung T, Hellström PM (2011) Blood chemistry markers for evaluation of inflammatory activity in Crohn's disease during infliximab therapy. Scand J Gastroenterol 46:420-427

13. Stephens RW, Nielsen HJ, Christensen IJ, Thorlacius-Ussing O, Sørensen S, Danø K, Brünner N (1999) Plasma urokinase receptor levels in patients with colorectal cancer: relationship to prognosis. J Natl Cancer Inst 91:869-874
14. Brunner N, Nielsen HJ, Hamers M, Christensen IJ, Thorlacius-Ussing O, Stephens RW (1999) The urokinase plasminogen activator receptor in blood from healthy individuals and patients with cancer. APMIS 107:160-167

15. Sidenius N, Sier CF, Ullum H, Pedersen BK, Lepri AC, Blasi F, Eugen-Olsen J (2000) Serum level of soluble urokinase-type plasminogen activator receptor is a strong and independent predictor of survival in human immunodeficiency virus infection. Blood 96:4091-4095

16. Ostrowski SR, Piironen T, HoyerHansen G, Gerstoft J, Pedersen BK, Ullum H (2005) High plasma levels of intact and cleaved soluble urokinase receptor reflect immune activation and are independent predictors of mortality in HIV-1-infected patients. J Acquir Immune Defic Syndr 39:23-31

17. Mizukami IF, Faulkner NE, Gyetko MR, Sitrin RG, Todd RF 3rd (1995) Enzyme-linked immuno-absorbent assay detection of a soluble form of urokinase plasminogen activator receptor in vivo. Blood 86:203-211

18. Bossuyt PM, Reitsma JB, Bruns DE, Gatsonis CA, Glasziou PP, Irwig LM, Lijmer JG, Moher D, Rennie D, de Vet HC, Standards for Reporting of Diagnostic Accuracy (2003) Towards complete and accurate reporting of studies of diagnostic accuracy: the STARD initiative. Standards for Reporting of Diagnostic Accuracy. Clin Chem 49:1-6

19. Bossuyt PM, Reitsma JB, Bruns DE, Gatsonis CA, Glasziou PP, Irwig LM, Moher D, Rennie D, de Vet HC, Lijmer JG (2003) The STARD statement for reporting studies of diagnostic accuracy: explanation and elaboration. Clin Chem 49:7-18 
20. Molkanen T, Ruotsalainen E, Thorball CW, Järvinen A (2011) Elevated soluble urokinase plasminogen activator receptor (suPAR) predicts mortality in Staphylococcus aureus bacteremia. Eur J Clin Microbiol Infect Dis 30:1417-1424

21. Moller HJ, Moestrup SK, Weis N, Wejse C, Nielsen H, Pedersen SS, Attermann J, Nexø E, Kronborg G (2006) Macrophage serum markers in pneumococcal bacteremia: prediction of survival by soluble CD163. Crit Care Med 34:2561-2566

22. Kofoed K, Andersen O, Kronborg G, Tvede M, Petersen J, Eugen-Olsen J, Larsen K (2007) Use of plasma C-reactive protein, procalcitonin, neutrophils, macrophage migration inhibitory factor, soluble urokinase-type plasminogen activator receptor, and soluble triggering receptor expressed on myeloid cells- 1 in combination to diagnose infections: a prospective study. Crit Care 11:R38

23. Kofoed K, Eugen-Olsen J, Petersen J, Larsen K, Andersen O (2008) Predicting mortality in patients with systemic inflammatory response syndrome: an evaluation of two prognostic models, two soluble receptors, and a macrophage migration inhibitory factor. Eur J Clin Microbiol Infect Dis 27:375-383

24. Kofoed K, Schneider UV, Scheel T, Andersen O, Eugen-Olsen J (2006) Development and validation of a multiplex add-on assay for sepsis biomarkers using xMAP technology. Clin Chem 52:1284-1293

25. Koch A, Voigt S, Kruschinski C, Sanson E, Dückers H, Horn A, Yagmur E, Zimmermann H, Trautwein C, Tacke F (2011) Circulating soluble urokinase plasminogen activator receptor is stably elevated during the first week of treatment in the intensive care unit and predicts mortality in critically ill patients. Crit Care 15:R63

26. Wittenhagen P, Kronborg G, Weis N, Nielsen H, Obel N, Pedersen SS, Eugen-Olsen J (2004) The plasma level of soluble urokinase receptor is elevated in patients with Streptococcus pneumoniae bacteraemia and predicts mortality. Clin Microbiol Infect 10:409-415

27. Huttunen R, Syrjanen J, Vuento R, Hurme M, Huhtala H, Laine J, Pessi T, Aittoniemi J (2011) Plasma level of soluble urokinase-type plasminogen activator receptor as a predictor of disease severity and case fatality in patients with bacteraemia: a prospective cohort study. J Intern Med 270:32-40
28. Florquin S, van den Berg JG, Olszyna DP, Claessen N, Opal SM, Weening JJ, van der Poll T (2001) Release of urokinase plasminogen activator receptor during urosepsis and endotoxemia. Kidney Int 59:2054-2061

29. Bone RC, Balk RA, Cerra FB, Dellinger RP, Fein AM, Knaus WA, Schein RM, Sibbald WJ, ACCP/SCCM Consensus Conference Committee (2009) Definitions for sepsis and organ failure and guidelines for the use of innovative therapies in sepsis. The ACCP/SCCM Consensus Conference Committee. American College of Chest Physicians/Society of Critical Care Medicine 1992. Chest 136(5 suppl):e28

30. Pierrakos C, Vincent JL (2010) Sepsis biomarkers: a review. Crit Care 14:R15

31. Christ-Crain M, Muller B (2007) Biomarkers in respiratory tract infections: diagnostic guides to antibiotic prescription, prognostic markers and mediators. Eur Respir $\mathbf{J}$ 30:556-573

32. Kibe S, Adams K, Barlow G (2011) Diagnostic and prognostic biomarkers of sepsis in critical care. J Antimicrob Chemother 66(Suppl 2):ii33-ii40

33. Standage SW, Wong HR (2011) Biomarkers for pediatric sepsis and septic shock. Expert Rev Anti Infect Ther 9:71-79

34. Becker KL, Snider R, Nylen ES (2008) Procalcitonin assay in systemic inflammation, infection, and sepsis: clinical utility and limitations. Crit Care Med 36:941-952

35. Schuetz P, Christ-Crain M, Muller B (2009) Procalcitonin and other biomarkers to improve assessment and antibiotic stewardship in infectionshope for hype? Swiss Med Wkly 139:318-326

36. Sier CF, Sidenius N, Mariani A, Aletti G, Agape V, Ferrari A, Casetta G, Stephens RW, Brünner N, Blasi F (1999) Presence of urokinase-type plasminogen activator receptor in urine of cancer patients and its possible clinical relevance. Lab Invest 79:717-722

37. Thuno M, Macho B, Eugen-Olsen J (2009) suPAR: the molecular crystal ball. Dis Markers 27:157-172

38. Ossowski L, Aguirre-Ghiso JA (2000) Urokinase receptor and integrin partnership: coordination of signaling for cell adhesion, migration and growth. Curr Opin Cell Biol 12:613-620

39. Resnati M, Guttinger M, Valcamonica S, Sidenius N, Blasi F, Fazioli F (1996) Proteolytic cleavage of the urokinase receptor substitutes for the agonistinduced chemotactic effect. EMBO J 15:1572-1582
40. Mondino A, Blasi F (2004) uPA and uPAR in fibrinolysis, immunity and pathology. Trends Immunol 25:450-455

41. Rijneveld AW, Levi M, Florquin S, Speelman P, Carmeliet P, van Der Poll $\mathrm{T}$ (2002) Urokinase receptor is necessary for adequate host defense against pneumococcal pneumonia. J Immunol 168:3507-3511

42. Selleri C, Montuori N, Ricci P, Visconte V, Carriero MV, Sidenius N, Serio B, Blasi F, Rotoli B, Rossi G, Ragno P (2005) Involvement of the urokinase-type plasminogen activator receptor in hematopoietic stem cell mobilization. Blood 105:2198-2205

43. Park YJ, Liu G, Tsuruta Y, Lorne E, Abraham E (2009) Participation of the urokinase receptor in neutrophil efferocytosis. Blood 114:860-870

44. Wiersinga WJ, Kager LM, Hovius JW, van der Windt GJ, de Vos AF, Meijers JC, Roelofs JJ, Dondorp A, Levi M, Day NP, Peacock SJ, van der Poll T (2010) Urokinase receptor is necessary for bacterial defense against pneumonia-derived septic melioidosis by facilitating phagocytosis. J Immunol 184:3079-3086

45. McMaken S, Exline MC, Mehta P, Piper M, Wang Y, Fischer SN, Newland CA, Schrader CA, Balser SR, Sarkar A, Baran CP, Marsh CB, Cook CH, Phillips GS, Ali NA (2011) Thrombospondin-1 contributes to mortality in murine sepsis through effects on innate immunity. PLoS ONE 6:e19654

46. Quach S, Hennessy DA, Faris P, Fong A, Quan H, Doig C (2009) A comparison between the APACHE II and Charlson index score for predicting hospital mortality in critically ill patients. BMC Health Serv Res 9:129

47. Le Gall JR, Lemeshow S, Saulnier F (1993) A new simplified acute physiology score (SAPS II) based on a European/North American multicenter study. JAMA 270:2957-2963

48. Mirsaeidi M, Peyrani P, Ramirez JA, Improving Medicine through Pathway Assessment of Critical Therapy of Hospital-Acquired Pneumonia (IMPACT-HAP) Investigators (2009) Predicting mortality in patients with ventilator-associated pneumonia: the APACHE II score versus the new IBMP-10 score. Clin Infect Dis 49:72-77

49. Riisbro R, Christensen IJ, Hogdall C, Brünner N, Høgdall E (2001) Soluble urokinase plasminogen activator receptor measurements: influence of sample handling. Int J Biol Markers 16:233-239 
50. Kumar A, Roberts D, Wood KE, Light 51. Moran JL, Bristow P, Solomon PJ, B, Parrillo JE, Sharma S, Suppes R, Feinstein D, Zanotti S, Taiberg L,

Gurka D, Kumar A, Cheang M (2006)

Duration of hypotension before initiation of effective antimicrobial therapy is the critical determinant of survival in human septic shock. Crit Care Med 34:1589-1596 George C, Hart GK, Australian and New Zealand Intensive Care Society Database Management Committee (ADMC) (2008) Mortality and lengthof-stay outcomes, 1993-2003, in the binational Australian and New Zealand intensive care adult patient database. Crit Care Med 36:46-61
52. Kaufmann PA, Smolle KH, Krejs GJ (2009) Short- and long-term survival of nonsurgical intensive care patients and its relation to diagnosis, severity of disease, age and comorbidities. Curr Aging Sci 2:240-248 